\title{
Tax evasion and financial repression: a reconsideration using endogenous growth models
}

\author{
Rangan Gupta, Department of Economics, University of Pretoria, Pretoria, South Africa
}

Emmanuel Ziramba, Department of Economics, University of Pretoria, Pretoria, South Africa

\begin{abstract}
Purpose - This paper aims at developing a theoretical model of a world economy characterized by tax evasion. It seeks to analyze whether financial repression can be explained by tax evasion.

Design/methodology/approach - The analysis is performed in overlapping generations dynamic general equilibrium endogenous monetary growth models.

Findings - The paper shows that higher degree of tax evasion within a country, resulting from a higher level of corruption and a lower penalty rate, yields higher degrees of financial repression.

Practical implications - Financial repression can be explained by tax evasion but under specific conditions.

Originality/value - This is the first attempt to analyze financial repression and tax evasion in an endogenous growth model.

\section{Introduction}

Using two overlapping generations dynamic general equilibrium endogenous monetary growth models[1] of a financially repressed economy, characterized by tax evasion (determined endogenously), we analyze whether financial repression can be explained by tax evasion. We follow Drazen (1989), Espinosa and Yip (1996), Haslag (1998), and Gupta (2008a, b) among others, in defining financial repression through an obligatory "high" reserve deposit ratio requirement, that banks in the economy need to maintain. The study attempts to assay whether there exists a plausible explanation as to why the reserve requirements in some economies are higher than others. Specifically, we investigate whether financial repression is an optimal policy outcome in the presence of tax evasion.
\end{abstract}

Financial repression was originally coined by economists interested in less-developed countries. Mckinnon (1973) and Shaw (1973), in their seminal, but independent, contributions were the first to spell out the notion of financial repression, defining it as a set of government legal restrictions preventing the financial intermediaries in the economy from functioning at full capacity. Generally, financial repression consists of three elements. First, the banking sector is forced to hold government bonds and money through the imposition of high reserve and liquidity 
ratio requirements. This allows the government to finance budget deficits at a low cost[2]. Second, given that the government revenue cannot be extracted easily from private securities, the development of private bond and equity markets is discouraged. Finally, the banking system is characterized by interest rate ceilings to prevent competition with public sector fund raising from the private sector and to encourage low-cost investment. Thus, the regulations generally include interest rate ceilings, compulsory credit allocation, and high reserve requirements. However, given the wave of interest rate deregulation in the 1980s, and removal credit ceiling some years earlier, the major form of financial repression is currently via obligatory reserve requirements[3]. There is still widespread evidence of financial repression, as pointed out by Espinosa and Yip (1996). The authors indicate that the concern is not whether financial repression is prevalent, but the associated degree to which an economy is repressed, since developed as well as developing countries both, resort to such restrictive practices.

The motivation for our analysis emanates from a recent paper by Gupta (2008b). In this paper, using a Solow-type overlapping generations framework, calibrated to four Southern European countries, the author analyzed the relationship between tax evasion, determined endogenously, and financial repression. Gupta (2008b) showed that higher degree of tax evasion within a country, resulting from a higher level of corruption and a lower penalty rate, yields higher degrees of financial repression as a social optimum. However, a higher degree of tax evasion, due to a lower tax rate, reduces the severity of the financial restriction. In addition, higher fraction of reported income, resulting from lower level of corruption or higher penalty rates, causes the government to inflate the economy at a higher rate. Money growth rate though, tends to fall, when an increase in the fraction of reported income originates from a fall in the tax rate.

At this juncture, it is important to put into perspective the study by Gupta (2008b) to better understand our motivation to extend the analysis. Note, tax evasion, amongst others[4], has been outlined, for example by Roubini and Sala-i-Martin (1995), Gupta (2005, 2006) and Holman and Neanidis (2006) by building on the empirical studies of Cuikerman et al. (1992) and Giovanni and De Melo (1993), as a possible rational for financial repression. However, Gupta (2008b) points out that all the above-mentioned theoretical analyses dealing with tax evasion and financial repression, suffer from a serious problem, in the sense, that they treat tax evasion as exogenous. The author stresses that the optimal degree of tax evasion is a behavioral decision made by the agents of the economy, and is likely to be affected by not only the structural parameters of the economy, but also the policy decisions of the government. Thus, all these models, essentially suffer from the "Lucas Critique" in some ways. Note, all the above studies, looked at the optimal policy decisions of the government following an increase in the exogenous rate of tax evasion, without specifying what is causing the change in the degree of evasion in the first place. Under such circumstances, the optimal choices made by the government is likely to be non-optimal, simply because, the degree of tax evasion, following such policy choices, would have changed the actual level of the tax evasion further, once we realize that tax evasion is endogenous. Hence, once one determines which policy variables, besides the structural parameters, are affecting the degree of tax evasion, they cannot be available to the government for use to respond optimally to a change in the degree of tax evasion.

Our objectives in this paper are two-fold: first, we want to see if the results of Gupta (2008b) continues to hold under the assumption of endogenous growth, with the endogeneity in the 
growth process obtained either via production externalities as in Romer (1986), or through productive public expenditure, as outlined in Barro (1990). The second of our objectives essentially follows from the fact that by incorporating a Barro-type model into our analysis, we are allowing for government expenditures productive, which, in turn, when compared to the Romer-type model, would allow us to assess the differences between the two alternative scenarios regarding the productivity capabilities of public expenditures. Note that both these extensions were in fact suggested by Gupta (2008b) as areas of further research.

This paper, thus, extends the work of Gupta (2008b), besides Roubini and Sala-i-Martin (1995), Gupta (2005, 2006) and Holman and Neanidis (2006), by re-evaluating the results in the presence of endogenous tax evasion, as in Atolia (2003), Chen (2003) and Arana (2004), and endogenous growth. To the best of our knowledge, such an attempt to rationalize financial repression based on endogenously determined tax evasion with the economy growing endogenously in steady state is the first of its kind.

To validate our analysis, as in Gupta (2008b), the theoretical model is numerically analyzed by calibrating it to four southern European economies, namely, Greece, Italy, Portugal and Spain. It must, however, be noted that our model is a general one and can be applied to any economy subjected to tax evasion. Our choice of countries has been mainly due data availability. Moreover, it has been argued that the chosen countries have had a tradition of high sizes of underground economy and, hence, tax evasion and high reliance on seigniorage, through high inflation rates and reserve requirements (Schneider and Klinglmair (2004), Gupta, 2008b).

This paper, thus, incorporates endogenous tax evasion in standard general equilibrium models of endogenous growth with overlapping generations. There are two primary assets in the model, namely, bank deposits and fiat money. Deposits dominate money in rate of return. An intermediary exists to provide a rudimentary pooling function, accepting deposits to finance the investment needs of the firms, but are subjected to mandatory cash-reserve requirements. There is also an infinitely-lived government with two wings: a Treasury which finances expenditure by taxing income and setting penalty for tax evasion when caught; and the central bank, which controls the growth rate of the nominal stock of money and the reserve requirements. In such an environment, we deduce the optimal degree of tax evasion, derived from the consumer optimization problem, as function of the parameters and policy variables of the model. The paper is organized as follows: Section 2 lays out the economic environment; Section 3, 4 and 5 respectively, are devoted in defining the monetary competitive equilibrium, discussing the process of calibration, and analyzing the welfare-maximizing choices of policy following an increase in tax evasion, resulting from either policy changes or alteration to a specific structural parameter of the model. Finally, Section 6 concludes.

\section{Economic environment}

Time is divided into discrete segments, and is indexed by $t=1,2, \ldots$ There are four types of economic activities:

1. Each two-period lived overlapping generations household (consumer/worker) is endowed with one unit of labor when young, but the agent retires when old. Thus, at time $t$, there 
are two coexisting generations of young and old. $N$ people are born at each time point $t=1$. At $t=1$, there exist $N$ people in the economy, called the initial old, who live for only one period. The population, $N$, is normalized to 1 . The young inelastically supplies one unit of the labor endowment to earn wage income, a part of the tax-liability is evaded, with evasion being determined endogenously to maximize utility, and the rest is deposited into banks for future consumption.

2. Each producer is infinitely lived and is endowed with a production technology to manufacture a single final good, using the inelastically supplied labor, physical capital and credit facilitated by the financial intermediaries.

3. The banks simply convert one period deposit contracts into loans, after meeting the cash reserve requirements. No resources are assumed to be spent in running the banks

4. There is an infinitely lived government, which meets its expenditure by taxing income, setting penalty for tax evasion when caught, and controlling the inflation tax instruments - the money growth rate and the reserve requirements. There is a continuum of each type economic agents with unit mass.

The sequence of events can be outlined as follows: When young a household works receives prepaid wages, evades a part of the tax burden and deposits the rest into banks. A bank, after meeting the reserve requirement, provides a loan to a goods producer, which subsequently manufactures the final good and returns the loan with interests. Finally the banks pay back the deposits with interests to households at the end of the first period and the latter consumes in the second period.

\subsection{Consumers}

Each consumer possesses a unit of time endowment that is supplied inelastically, and consumes only when old. Formally the problem of the consumer can be described as follows: The utility of a consumer born at $t$ depends on real consumption, $c_{t+1}$, which implies that the consumer consumes when old. This assumption makes computation tractable and is not a bad approximation of the real world (see Hall, 1988). Consumers have the same preferences so there exists a representative consumer in each generation. The consumer is assumed to be risk averse.

For the potential evader, there are (ex ante) two possible situations: "success” (i.e. getting away with evasion) and "failure" (i.e. getting discovered and being convicted). If the consumer is fought guilty of concealing an amount of income $(1-\beta) p_{t} w_{t}$, then has to pay the amount of the evaded tax liability, $(1-\beta) \tau_{t} p_{t} w_{t}$ and a proportional fine at a rate of $t_{t}>1$. Thus, the household incurs transaction costs in order to evade taxes. Such costs take the form of expenses of hiring lawyers to avoid/reduce tax burdens, and bribes paid to tax officials and administrators. The transaction costs are assumed to be increasing in both the degree of tax evasion and the wage income of the household. They take the form $\eta(1-\beta)^{2} p_{t} w_{t}$. Note a higher value of $\eta$, would imply a less corrupted economy, implying that it is more difficult to evade taxes. The probability of getting caught, $1-q$, is also endogenized, by assuming it to be an increasing function of the degree of tax evasion. This probability of getting caught, $1-q$ takes the following quadratic form: 


$$
1-q=(1-\beta)^{2} \text {. }
$$

Formally, the consumer solves the following problem:

$$
\frac{d}{d \beta}\left[\left\{1-(1-\beta)^{2}\right\} U\left(c_{t+1}^{1}+(1-\beta)^{2} U\left(c_{t+1}^{2}\right)\right]=0\right.
$$

where, $c_{t+1}{ }^{1}$ and $c_{t+1}{ }^{2}$ are the consumption levels when the consumer can evade taxes with success and failure, respectively, which can be described mathematically as follows:

$$
\begin{gathered}
c_{t+1}^{1}=\left(1+r_{D t+1}\right)\left[\left(1-\beta \tau_{t}\right)-\eta(1-\beta)^{2}\right] w_{t} \\
c_{t+1}^{2}=\left(1+r_{D t+1}\right)\left[\left(1-\beta \tau_{t}-\theta_{t} \tau_{t}(1-\beta)-\eta(1-\beta)^{2}\right] w_{t}\right.
\end{gathered}
$$

where $p_{t}$ is the price level at time, $t, w_{t}$ is the real wage at $t$ and $i_{D t+1}$ is the nominal interest rate received on the investments at $t+1$. The respective sizes of household deposit when he or she successfully or unsuccessfully evades taxes are measured by $\left[\left(1-\beta \tau_{t}\right)-\eta(1-\beta)^{2}\right] w_{t}$ and $\left[\left(1-\beta \tau_{t}\right)-\right.$ $\left.{ }_{t} \tau_{t}(1-\beta)-\eta(1-\beta)^{2}\right] w_{t}$ respectively. Thus, $d_{t}=\left[\left(1-\beta \tau_{t}\right)-{ }_{t}(1-\beta)^{3}-\eta(1-\beta)^{2]} w_{t}\right.$ gives the size of the expected aggregate real deposits in the economy, given that $N=1$. Finally, we assume a utility function of the following form, for $i=1,2$ :

$$
U\left(c_{t+1}^{i}\right)=\frac{\left(c_{t+1}^{i}\right)^{(1-\sigma)}}{1-\sigma}
$$

where $U$ is twice differentiable; $u^{\prime}>0 ; u^{\prime \prime}<0$ and $u^{\prime}(0)=\infty$.

\subsection{Financial intermediaries}

Financial intermediaries provide a simple pooling function by accepting deposits at the beginning of each period. They then make their portfolio decision (that is, loans and cash reserve choices) with a goal of maximizing profits. At the end of the period they receive their interest income from the loans made and meet the interest obligations on deposits received. For simplicity bank deposits are assumed to be one period contract. The intermediaries are constrained by legal requirements on the choice of their portfolio (that is, reserve requirements), 
as well as by feasibility. Given such a structure, the intermediaries obtain the optimal choice for $L_{t}$ by solving the following problem:

$$
\begin{aligned}
& \max _{L, D} \Pi_{b}=i_{L t} L_{t}-i_{D t} D_{t} \\
& \text { s.t. : } \gamma_{t} D_{t}+L_{t} \leq D_{t}
\end{aligned}
$$

where $\Pi_{b}$ is the profit function for the financial intermediary; $D_{t}$ is the per-capita nominal deposits, and $M_{t} \geq \gamma_{t} D_{t}$ defines the legal reserve requirement. $M_{t}$ is the cash reserves held by the bank; $L_{t}$ is the loans; $i_{L t}$ is the interest rate on loans, and; $\gamma_{t}$ is the reserve requirement ratio. The reserve requirement ratio is the ratio of required reserves (which must be kept in the form of currency) to deposits received. To begin some economic intuition of the role of reserve requirements, let us consider the solution of the problem for a typical intermediary. It is assumed that financial intermediaries behave competitively and free entry drives profits to zero and we have:

$$
i_{L t}\left(1-\gamma_{t}\right)-i_{D t}=0
$$

Simplifying, in equilibrium, the following condition must hold:

$$
i_{L t}=\frac{i_{D t}}{1-\gamma_{t}}
$$

Reserve requirements thus tend to induce a wedge between the interest rate on savings and lending rates for the financial intermediaries.

\subsection{Firms}

All firms are identical and produce a single final good using the following production technologies:

$$
y_{t}=A k_{t}^{\alpha}\left(n_{t} k_{t}\right)^{(1-\alpha)}
$$




$$
y_{t}=A k_{t}^{\alpha}\left(n_{t} g_{t}\right)^{(1-\alpha)}
$$

where $A>0 ; 0<\alpha((1-\alpha))<1$, is the elasticity of output with respect to capital (labor), with $k_{t}, n_{t}$ and $g_{t}$ respectively denoting capital, labor, and government expenditure inputs at time $t$. At time $t$ the final good can either be consumed or stored. We assume that producers are able to convert bank loans $L_{t}$ into fixed capital formation such that $p_{t} i_{k t}=L_{t}$, where $i_{t}$ denotes the investment in physical capital. In each of the respective technologies the production transformation schedule is linear so that the same technology applies to both capital formation and the production of the consumption good and hence both investment and consumption good sell for the same price $p$. We follow Diamond and Yellin (1990) and Chen et al. (2000) in assuming that the goods producer is a residual claimer, that is, the producer uses up the unsold consumption good in a way that is consistent with lifetime value maximization of the firms. This assumption regarding ownership avoids the "unnecessary" Arrow-Debreu redistribution from firms to consumers and simultaneously retains the general equilibrium structure of the models.

The representative firm maximizes the discounted stream of profit flows subject to the capital evolution and loan constraint. Formally, the problem of the firm can be outlined as follows:

$$
\begin{gathered}
\max _{k_{t+1}, n_{t}} \sum_{i=0}^{\infty} \rho^{i}\left[p_{t} y_{t}-p_{t} w_{t} n_{t}-\left(1+i_{L t}\right) L_{t}\right] \\
K_{t+1}=\left(1-\delta_{k}\right) k_{t}+i_{k t} \\
P_{t} i_{k t} \leq L_{t} \\
L_{t} \leq\left(1-\gamma_{t}\right) D_{t}
\end{gathered}
$$

where $\rho$ is the firm owners (constant) discount factor, and $\delta_{k}$ is the (constant) rate of capital depreciation. The firm solves the above problem to determine the demand for labor and investment. The firm's problem can be written in the following respective recursive formulations: 


$$
\begin{aligned}
V\left(k_{t}\right)= & \max _{n, k^{\prime}}\left[p_{t} A k_{t}^{\alpha}\left(n_{t} k_{t}\right)^{(1-\alpha)}-p_{t} w_{t} n_{t}-p_{t}\left(1+i_{L t}\right)\left(k_{t+1}-\left(\left(k_{t+1}-\left(1-\delta_{k}\right) k_{t}\right) k_{t}\right)\right]\right. \\
& +\rho V\left(k_{t+1}\right)
\end{aligned}
$$

$$
\begin{aligned}
V\left(k_{t}\right)= & \max _{n, k^{\prime}}\left[p_{t} A k_{t}^{\alpha}\left(n_{t} g_{t}\right)^{(1-\alpha)}-p_{t} w_{t} n_{t}-p_{t}\left(1+i_{L t}\right)\left(k_{t+1}-\left(1-\delta_{k}\right) k_{t}\right)\right] \\
& +\rho V\left(k_{t+1}\right) .
\end{aligned}
$$

The upshot of the above dynamic programming problems are the following respective first order conditions:

$$
\begin{gathered}
k_{t+1}:\left(1+i_{L t}\right) p_{t}=p_{t+1} \rho\left[A \alpha+\left(1-\delta_{k}\right)\left(1+i_{L t+1}\right)\right] \\
\left(n_{t}\right): A(1-\alpha) k_{t}=w_{t} \\
k_{t+1}:\left(1+i_{L t}\right) p_{t}=\rho p_{t+1}\left[A \alpha\left(\frac{g_{t+1}}{k_{t+1}}\right)^{1-\alpha}+\left(1+i_{L t+1}\right)\left(1-\delta_{k}\right)\right] \\
\left(n_{t}\right): A(1-\alpha)\left(\frac{g_{t}}{k_{t}}\right)^{(1-\alpha)} k_{t}=w_{t} .
\end{gathered}
$$

Equations (18) and (20) provide the conditions for the optimal investment decisions of the firm. The firm compares the cost of increasing investment in the current period with the future stream of benefits generated from the extra capital invested in the current period. Equations (19) and (21) state that the firm hires labor up to the point where the marginal product of labor equates the real wage.

\subsection{Government}

The government is assumed to be infinitely-lived. It purchases $g_{t}$ units of the consumption good. In the Romer-type model government expenditure is non-productive, while, in the Barro-type model government expenditures are productive to the agents. Government expenditures are 
financed through income taxation, penalty rate and seigniorage. In real per-capita terms the government budget constraint can be written as follows:

$$
g_{t}=\left[\beta+(1-q) \theta_{t}(1-\beta)\right] \tau_{t} w_{t}+\gamma_{t} d_{t}\left(1-\frac{1}{\mu_{t}}\right)
$$

where $\mu_{t}$ is the gross money supply growth rate, $m_{t}=\mu_{t} m_{t-1}$ and $d_{t}$ is the per capita real deposits.

Skinner and Slemrod (1985) points out that the administrative costs of penalties is usually quite minor, and, hence, for simplicity we ignore them from the government budget constraint. However, the costs involved in auditing the households have been ignored due to the unavailability of information on such costs for our sample of countries. But adding an extra dimension of cost, merely implies an increase in the public expenditures and an inflated level of the policy parameters, without qualitatively changing our results.

\section{Equilibrium}

A competitive equilibrium for this economy is a sequence of prices $\left\{p_{t}, i_{t}, i_{L t}\right\}_{t=0}^{\infty}$, allocations $\left\{c_{t+1}{ }^{1}, c_{t+1}{ }^{2}, n_{t}, i_{k t}\right\}_{t=0}{ }^{\infty}$, stocks of financial assets $\left\{m_{t}, d_{t}\right\}_{t=0}{ }^{\infty}$, and policy variables $\left\{\gamma_{t}, \mu_{t}, \tau_{t}\right.$ $\left., t, g_{t}\right\}_{t=0}{ }^{\infty}$ such that:

- $\tau_{t}, g_{t}, t, \gamma_{t}, \mu_{t}, p_{t}, r_{D t+1}$ and $w_{t}$, the consumer optimally chooses $\beta$ such that (2) holds;

- $\quad$ banks maximize profits, taking $i_{L t}, i_{D t}$, and $\gamma_{t}$ as given and such that (9) holds;

- the real allocations solve the firm's date $-t$ profit maximization problem, given prices and policy variables, such that (18), (19), (20) and (21) hold;

- the money market equilibrium conditions: $m_{t}=\gamma_{t} d_{t}$ is satisfied for all $t \geq 0$;

- the loanable funds market equilibrium condition: $p_{t} i_{k t}=\left(1-\gamma_{t}\right) D_{t}$ where the total supply of loans $L_{t}=\left(1-\gamma_{t}\right) D_{t}$ is satisfied for all $t \geq 0$;

- the goods market equilibrium condition require: $c_{t}+i_{k t}+g_{t}=y_{t}-\eta(1-\beta)^{2} w_{t}$ is satisfied for all $t \geq 0$;

- $\quad$ the labor market equilibrium condition: $\left(n_{t}\right)^{d}=1$ for all $t \geq 0$;

- the government budget is balanced on a period-by-period basis; and

- $d_{t}, r_{d t}, r_{L t}$, and $p_{t}$ must be positive at all dates.

\section{Calibration}

In this section, we attribute parameter values to our model by using a combination of figures from previous studies and facts about the economic experience for our sample economies between 1980 and 1998. We follow standard real business cycle literature in using steady-state conditions to estimate parameter values observed in the data. Some parameters are calibrated using country-specific data, while others correspond to prevailing values from the literature. The endogenous variable are the gross growth rate, $\chi$, the annual inflation rate, $\pi$, and the nominal interest rate on loans, $i_{L t}$. These are assign values in order to calibrate values for the other 
parameters reported in Table I. A first set of parameter values is given by numbers usually found in the literature. These are:

- $\sigma$ : the degree of risk aversion, as stated above, is set to 2 .

- $\quad \alpha$ : since the production function is Cobb-Douglas, this corresponds to the share of capital in income. The values of $(1-\alpha)$ for all the countries were obtained from Gupta (2008b). The values of $\alpha$ lie between 37.3 percent (Spain) and 47 percent (Portugal).

- $\delta_{k}$ : the depreciation rate of physical capital was also obtained from Gupta (2008b). The values lie between 3.2 percent (Greece) and 5.2 percent (Italy).

- : the penalty imposed by the government when the consumer is caught evading is obtained from Chen (2003) and is set to 1.5 for all countries.

- $\quad \gamma$ : the annual reserve-deposit ratio as a percentage. The values lie between 13.7 percent (Italy) and 23.5 percent (Greece).

- $\tau$ : tax rate, calculated as the ratio of tax receipts to gross domestic product. The values lie between 22.74 percent (Greece) and 36.25 percent (Italy).

- $\quad \beta$ : the fraction of reported income. The values lie between 0.775 (Greece) and 0.81 (Spain and Portugal).

- $\quad \lambda$ : the discount factor expressed at an annual rate. It was obtained from Chari et al. (1995) and is set to 0.98 for all countries.

A second set of parameters are calibrated from the steady-state equations of the models to make them hold exactly (Table II). These parameters are:

\begin{tabular}{lcccccccc}
\hline & $\alpha$ & $\delta_{k}$ & $\pi$ & $\gamma$ & $\tau$ & $i_{L}$ & $\beta$ & $x$ \\
\hline Spain & 0.373 & 0.05 & 7.52 & 14.1 & 25.53 & 12.89 & 0.810 & 1.0254 \\
Italy & 0.383 & 0.052 & 8.58 & 13.7 & 36.25 & 15.02 & 0.786 & 1.0193 \\
Greece & 0.402 & 0.032 & 15.16 & 23.5 & 22.74 & 22.96 & 0.775 & 1.0186 \\
Portugal & 0.470 & 0.05 & 13.04 & 19.8 & 27.73 & 19.09 & 0.810 & 1.0295
\end{tabular}

Table I. Notes: Parameters defined as above with $\sigma=2 ; \theta=1.5$; and $\lambda=0.98$ Parameter values $\quad$ Source: Gupta (2008a, b)

Table II.

Calibrated parameter values

\begin{tabular}{lcccccccc}
\hline & \multicolumn{9}{c}{${ }^{2}$} & \multicolumn{2}{c}{$A$} & \multicolumn{2}{c}{$\rho$} & \\
& $\eta$ & $\mu$ & Romer & Barro & Romer & Barro & Romer & Barro \\
\hline Spain & 0.5372 & 1.103 & 0.1381 & 1.835 & 0.9209 & 0.9205 & 0.025 & 0.025 \\
Italy & 0.6270 & 1.107 & 0.1966 & 1.521 & 0.9087 & 0.9085 & 0.0363 & 0.0364 \\
Greece & 0.3751 & 1.173 & 0.1381 & 1.579 & 0.8571 & 0.8566 & 0.0172 & 0.0174 \\
Portugal & 0.5934 & 1.164 & 0.2490 & 1.429 & 0.8439 & 0.8540 & 0.0328 & 0.0286 \\
\multicolumn{2}{l}{ Note: Parameters defined as above } & & & & & \\
\end{tabular}

- $\mu$ : the gross money growth rate is calibrated using the growth rate and the inflation rate for each country. The value lies between 1.1030 (Spain) and 1.1730 (Greece).

- $\eta$ : the cost parameter measuring the resources spent by the households to reduce their tax burden is calibrated to ensure that the degree of tax evasion matches the given values of $1-\beta$. The value lies between 0.3751 (Greece) to 0.6270 (Italy). Note that these values are obtained based from the second root out of the six. For the other roots, we could not obtain fractional values[5] of $\eta$, required to ensure that the degree of tax evasion 
corresponds to our calculations made above. As a result, based on our choice of $\eta$, we eliminate the other five roots.

- $\quad \rho$ : the discount factor of the firms is solved to ensure that equations (22) and (24) hold in both the models for each country. The value ranges between 0.8439 (Portugal) to 0.9209 (Spain) for the Romer-type model. While, the same ranges between 0.8540 (Portugal) to 0.9205 (Spain).

- $A$ : the value of the production function scalar, is calibrated from the equilibrium conditions to match the growth rates and the inflation rates for each country. The value lies between 0.1381 (Spain and Greece) in the Romer-type model and 1.8346 and 0.2490 (Portugal). While, for the Barro model the same ranges between 1.4285 (Portugal) and 1.8346 (Spain).

- $\quad b$ : the government expenditure to capital ratio, is calibrated from the government budget constraint. The value lies between 0.0172 (Greece) and 0.0363 (Italy) for the Romer-type model, while, the same value ranges between 0.0174 (Greece) to 0.0364 (Italy).

\section{Welfare-maximizing monetary policy in the presence of endogenous tax evasion}

In this section, we analyze whether higher degree of tax evasion would result in an increase in the degree of financial repression within a specific country. For this purpose, we study the behavior of a social planner who maximizes the utility of all consumers, by choosing $\gamma$ and $\mu$, subject to the set of inequality constraints: $0 \leq \gamma \leq 1, \mu \geq 0$ and the government budget constraint, equation (22), evaluated at the steady state, following changes in $\beta^{*}$. The social planner maximizes the discounted stream of life-time consumer utility, specifically with the discount rate

$$
0<\lambda<1, \sum_{i=0}^{\infty} \lambda^{i}\left[-\left\{1-(1-\beta)^{2}\right\} \frac{1}{\left(c_{t+1+i}^{1}\right)}-(1-\beta)^{2} \frac{1}{\left(c_{t+1+i}^{2}\right)}\right] \text {, given that } \sigma=2 \text {. }
$$

First, we derive the optimal values of $\gamma$ and $\mu$ for the steady-state values of $\beta=\beta^{*}$. We assume that the government follows time invariant policy rules, which means that the institutionally determined tax rate, $\tau_{t}$, the cash reserve ratio, $\gamma_{t}$, the money growth rate, $\mu_{t}$, the level of government expenditure, $g_{t}$ are constant over time. These are reported in Tables III and IV. We then analyze the movements of the optimal values of monetary policy parameters, following a one percentage point increase in $\beta^{*}$ solely due to a change in either $\eta, \tau$ or , as three separate cases. For this purpose, the values of $\eta, \tau$ and were re-calibrated, but are not reported in this paper. The optimal values of the monetary policy variables, corresponding to $\beta=\beta^{*}$ and $\beta^{*}+0.01$, arising solely due to a change in either $\eta$ or $\tau$ or , are also reported in Table IV [6].

The following inferences can be made drawn based on the results reported in Tables III and IV:

- In the Romer-type model, a one percentage point increase in the reported income, emerging from an increase in $\eta$ and , causes the optimal value of the reserve requirement $\left(\gamma^{*}\right)$ and the optimal money growth rate $\left(\mu^{*}\right)$ to fall, for all the countries. However, when the increase in the reported income is due to a fall in the tax rate, $\gamma^{*}$ and $\mu^{*}$ rise. 
- Similar movements of the optimal reserve requirement $\left(\gamma^{*}\right)$ and the optimal money growth rate $\left(\mu^{*}\right)$ are observed for all the countries in the Barro-type model with productive public expenditures.

- Thus, a higher degree of tax evasion, (a fall in $\beta^{*}$ ) does imply higher level of financial restrictions for all countries, irrespective of whether government expenditure is productive or not.

Intuitively, the effects of the changes in , $\eta$ and $\tau$ on $\gamma$ and $\mu$ can be explained as follows: First of all, let us consider the effect of an increase in the penalty rate on the model and the resulting effect on $\gamma$ and $\mu$ as part of an optimal policy plan of the consolidated government. An increase in the penalty rate causes reported income and the tax burden to increase which, in turn, reduces the deposits, and, hence, growth and welfare. Clearly, the optimal response now for the government would be to reduce the reserve requirements so that the size of loans (investment) could be increased to maintain higher growth and welfare in the face of falling deposits. In addition to lowering the reserve requirements, the government also reduces the money growth rate, both of which tend to increase the real interest rate on deposits and, hence, welfare. Finally, lower reserve requirements and money growth rate also ensures that the government budget constraint holds, since, the increase in the tax revenue following an increase in the penalty rate needs to be compensated by a fall in the seigniorage.

\begin{tabular}{|c|c|c|c|c|c|c|c|c|c|}
\hline & & \multicolumn{2}{|c|}{$\beta^{*}$} & \multicolumn{2}{|c|}{$(\eta)$} & \multicolumn{2}{|c|}{$\begin{array}{c}\left(\beta^{*}+0.01\right) \\
(\theta)\end{array}$} & \multicolumn{2}{|c|}{$(\tau)$} \\
\hline & & $\gamma$ & $\mu$ & $\gamma$ & $\mu$ & $\gamma$ & $\mu$ & $\gamma$ & $\mu$ \\
\hline \multirow{5}{*}{$\begin{array}{l}\text { Table III. } \\
\text { Optimal monetary policy } \\
\text { parameters in the } \\
\text { Romer-type model }\end{array}$} & Spain & 0.6582 & 2.1019 & 0.6575 & 2.0929 & 0.6577 & 2.0930 & 0.6670 & 2.1075 \\
\hline & Italy & 0.6127 & 2.1229 & 0.6112 & 2.1041 & 0.6120 & 2.0559 & 0.6265 & 2.2280 \\
\hline & Greece & 0.7012 & 1.0520 & 0.6818 & 1.0500 & 0.6626 & 1.0500 & 0.7497 & 1.0700 \\
\hline & Portugal & 0.6974 & 1.0744 & 0.6967 & 1.0600 & 0.4993 & 1.0500 & 0.7044 & 1.0808 \\
\hline & \multicolumn{9}{|c|}{ Note: Parameters defined as above } \\
\hline
\end{tabular}

\begin{tabular}{|c|c|c|c|c|c|c|c|c|c|}
\hline & & \multicolumn{2}{|c|}{$\beta^{*}$} & \multicolumn{2}{|c|}{$(\eta)$} & \multicolumn{2}{|c|}{$\begin{array}{c}\left(\beta^{*}+0.01\right) \\
(\theta)\end{array}$} & \multicolumn{2}{|c|}{$(\tau)$} \\
\hline & & $\gamma$ & $\mu$ & $\gamma$ & $\mu$ & $\gamma$ & $\mu$ & $\gamma$ & $\mu$ \\
\hline \multirow{5}{*}{$\begin{array}{l}\text { Table IV. } \\
\text { Optimal monetary policy } \\
\text { parameters in the } \\
\text { Barro-type model }\end{array}$} & Spain & 0.7699 & 3.6663 & 0.7697 & 3.6556 & 0.7698 & 3.6516 & 0.7735 & 3.7585 \\
\hline & Italy & 0.9007 & 2.9619 & 0.8993 & 2.8908 & 0.9001 & 2.8975 & 0.9137 & 3.7991 \\
\hline & Greece & 0.7644 & 3.3393 & 0.7641 & 3.3314 & 0.7616 & 3.2784 & 0.7669 & 3.3959 \\
\hline & Portugal & 0.8960 & 3.8049 & 0.8956 & 3.7133 & 0.8935 & 3.4981 & 0.9049 & 4.9615 \\
\hline & \multicolumn{9}{|c|}{ Note: Parameters defined as above } \\
\hline
\end{tabular}

The explanation, given above, is identical for a change in $\eta$ affecting the economy and, hence, the policy decisions of the government.

As far as the effects of lower tax rate are concerned, the intuition is similar, but flows in the opposite direction. Given that the size of tax collection has declined, even though, lower taxes increase reported income but does so less than proportionately, the government has to ensure that its budget constraint holds, and this can only be achieved by increasing the revenue from seigniorage. This in turn requires an increase in the money growth rate and the reserve requirements. However, note, the increase in these two variables are changed optimally so that 
the fall in the growth rate[7], due to lower investment resulting from higher reserve requirements, and the fall in the real interest rate on deposits due to higher money growth rate and higher reserve requirement does not compromise the welfare of the individuals.

In the Barro-type model, the intuitive explanations are more or less similar, except for the fact that now one has to realize that the ratio of the government expenditure to capital plays an important role in the growth process directly. So for an increase in the penalty rate and a decrease in the level of corruption, or alternatively, increase in $\eta$, the fall in the reserve requirements and money growth rate tends to affect the deposits and the real interest rate on the deposits in similar fashion as that in the Romer-type model, however, the government needs to ensure the fall in seigniorage does not overpower the increase in the tax revenue, and hence, negatively affect growth and welfare. On the other hand, following lower tax rates, the growth rate, and, hence, welfare increases directly, as the size of deposits, loans and, hence, investment increases. However, the decline in the tax rate also tends to have a negative effect on the growth rate as the ratio of public capital to physical capital tends to decline. In order to ensure that the latter effect does not outweigh the former effect, the government responds by increasing the seigniorage revenue, via increases in both reserve requirement and the money growth rate, but simultaneously, making sure that the associated fall in the real interest rate and also the size of the loans and, hence, investment, does not cause welfare to fall below the optimal level.

In summary, when compared to Gupta (2008b), our results regarding the movement of the reserve requirement is identical. Specifically, we conclude that irrespective of whether we have no-growth or positive-growth in the steady state, higher degree of tax evasion within a country due to a higher level of corruption or lower penalty rates, leads to a higher degree of financial repression. However, a higher degree of tax evasion due to a higher tax rate leads to a reduction in the severity of financial restriction. The difference with Gupta (2008b), however, lies in the movement of the money growth rate, and, hence inflation. Interestingly, the movements are exactly the opposite, i.e. unlike Gupta (2008b), money growth rate moves in the same direction as that of the reserve requirements following changes in the degree of tax evasion arising out of changes in the penalty rate, the degree of corruption or the tax rate.

At this stage, it is important to compare our results with that of the work done by Roubini and Sala-i-Martin (1995). Note, the authors pointed out that governments subjected to large taxevasion will "choose to increase seigniorage by repressing the financial sector and increasing the inflation rates." In our case though, this result only holds if the increase in the degree of tax evasion results from a lower penalty rate or higher level of corruption, i.e. lesser fraction of resources is needed to be spent to evade tax. Hence, our analysis points out the importance of modeling tax evasion as an endogenous decision. It is also important to stress that our paper is more comparable to that of the Roubini and Sala-i-Martin (1995) analysis, relative to Gupta (2008b), since we like Roubini and Sala-i-Martin (1995) base our conclusions on an endogenous growth model. Hence, our study should be viewed as an analysis that qualifies the work of Roubini and Sala-i-Martin (1995) by pointing out that higher tax evasion leads to higher financial repression and inflation only under certain conditions. 


\section{Conclusions}

Using two overlapping generations dynamic general equilibrium endogenous monetary growth models, we analyze the relationship between tax evasion, determined endogenously, and financial repression. Following the broad literature, we define financial repression through an obligatory "high" reserve deposit ratio requirement. The study attempts to assay whether there exists a plausible explanation as to why the reserve requirements in some economies are higher than others. Specifically, we analyze whether the "high" reserve requirements are a fall out of a welfare maximizing decision of the government, in an economy characterized by endogenous tax evasion.

When numerically analyzed for four Southern European countries, the following conclusions could be drawn:

- Higher degree of tax evasion within a country, resulting from lower penalty rates and higher corruption, produces socially optimum higher degrees of financial repression, i.e. a higher value of the reserve requirement. However, higher degrees of tax evasion, due to higher tax rates, tend to reduce the optimal degree of financial repression.

- Higher fraction of reported income, resulting from lower level of corruption or higher penalty rates, causes the government to inflate the economy at a lower rate. Money supply growth rate, however, tends to rise, when an increase in the fraction of reported income originates from a fall in the tax rate.

- Finally, find the results to be robust across growth models without or with productive public expenditures. The only difference being that the policy parameters have higher optimal values in the latter case.

So in summary, from a policy perspective, the model suggests that, an increase in the degree of evasion within the country, resulting from lower penalty rates or higher corruption, should be followed by an increase in the reserve requirements and an increase in the money growth rate as part of a welfare maximizing behavior of the consolidated government. However, higher tax evasion due to higher tax rates, causes the growth rate of money supply and the reserve requirement to fall. Our paper, thus, concludes that there exist asymmetries in optimal monetary policy decisions, depending on what is causing a change in the degree of tax evasion. More importantly though, tax evasion and financial repression are positively correlated, if and only if, the change in the former results from an alteration in the penalty rate or the level of corruption. In addition, by extending the analysis of Gupta (2008b), this paper also shows that irrespective of whether we have no-growth or positive- growth in the steady state, higher degree of tax evasion within a country due to a higher level of corruption and a lower penalty rate can lead to higher degrees of financial repression. These results, in turn, also refines the work of Roubini and Salai-Martin (1995), who claimed that higher degrees of tax evasion always accompanies higher levels of financial repression and inflation. As we show here, this result is contingent on identifying what is causing the tax evasion to change, and is not always an obvious outcome. 


\section{Acknowledgements}

The authors would like to thank an anonymous JEL classification - E26; E63 referee whose comments benefited the paper immensely while being reviewed for the Economic Research Southern Africa (ERSA) working paper series. Finally, they gratefully acknowledge the financial support of ERSA in completing this study.

\section{Notes}

1. For a recent application of an endogenous growth model see Creed and Gemmell (2005)

2. See Kandil (2006) for details on the effects of government spending.

3. See Demirguç-kunt and Detragiache (2000) for further details.

4. Other possible explanations as to why governments across the world would want to resort to financial repression has ranged from imperfect information and the possibility of banking crisis (Gupta, 2005, 2006) to currency substitution (Gupta, 2008a).

5. Either none or imaginary values were obtained for $\eta$ from the other roots.

6. Note, the model does not analyze the possibility of transitional dynamics following a change in $\beta^{*}$. Here, we are merely interested in figuring out the movements of $\mu$ and $\gamma$ following a change in the value of $\beta^{*}$ across steady states.

7. Note that lower tax rate, however, tends to increase the growth rate at first, which might in fact cause the economy to overshoot the welfare-maximizing level.

\section{References}

Arana, O.M.V. (2004), "Economic growth and the household optimal income tax evasion”, Discussion Paper No. 275, Department of Economics, Universidad Nacionale de Colombia, Bogotá.

Atolia, M. (2003), “An OLG model of tax evasion with public capital”, working paper, Florida State University, Tallahassee, FL..

Barro, R.J. (1990), "Government spending in a simple model of endogenous growth", Journal of Political Economy, Vol. 98 No.5, Part 2, pp.s103-25.

Chari, V., Manuelli, R.E., Jones, L.E. (1995), "The growth effects of monetary policy", Quarterly Review, Federal Reserve Bank of Minneapolis, Vol. 19 No.4, pp.18-32.

Chen, B.L. (2003), "Tax evasion in a model of endogenous growth", Review of Economic Dynamics, Vol. 6 No.2, pp.381-403.

Chen, B.L., Chiang, Y.Y., Wang, P. (2000), “Credit market imperfections, financial activity and economic growth”, Working Paper No. 00-W20, Vanderbilt University, Nashville, TN.

Creedy, J., Gemmell, N. (2005), "Publicly financed education in an endogenous growth model", Journal of Economic Studies, Vol. 32 No.2, pp.114-31. 
Cuikerman, A., Sebastian, E., Tabellini, G. (1992), "Seigniorage and political instability", American Economic Review, Vol. 82 No.3, pp.537-55.

Demirguç-kunt, A., Detragiache, E. (2000), "Financial liberalization and financial fragility", in Caprio, G., Honohan, P., Stiglitz, J.E. (Eds),Financial Liberalization - How Far, How Fast?, Cambridge University Press, Cambridge, pp.96-124.

Diamond, P., Yellin, J. (1990), "Inventories and money holdings in a search economy", Econometrica, Vol. 58 No.4, pp.929-50.

Drazen, A. (1989), "Monetary policy, seigniorage, and capital controls in an open economy", in de Cecco, M., Giovannini, A. (Eds),A European Central Bank?, Cambridge University Press, Cambridge, pp.13-52.

Espinosa, M., Yip, C.K. (1996), “An endogenous growth model of money, banking, and financial repression”, Working Paper No. 96-4, Federal Reserve Bank of Atlanta, Atlanta, GA, .

Giovanni, A., De Melo, M. (1993), "Government revenue from financial repression", American Economic Review, Vol. 83 No.4, pp.953-63.

Gupta, R. (2005), "Costly state monitoring and reserve requirements", Annals of Economics and Finance, Vol. 6 No.2, pp.263-88.

Gupta, R. (2006), "Asymmetric information, tax evasion and alternative instruments of government revenue", The ICFAI Journal of Monetary Economics, Vol. IV No.1, pp.75-89.

Gupta, R. (2008a), “Currency substitution and financial repression”, Working Paper 06, Department of Economics, University of Pretoria, Pretoria..

Gupta, R. (2008b), "Tax evasion and financial repression", Journal of Economics and Business, Vol. 60 No.6, pp.517-35.

Hall, R.E. (1988), "Intertemporal substitution in consumption", Journal of Political Economy, Vol. 96 No.2, pp.339-57.

Haslag, J.H. (1998), "Monetary policy, banking and growth", Economic Inquiry, Vol. XXXVI No.3, pp.489-500.

Holman, J.A., Neanidis, K.C. (2006), "Financing government expenditure in an open economy", Journal of Economic Dynamics and Control, Vol. 30 No.8, pp.1315-37.

Kandil, M. (2006), "The growth of government spending and the money supply: Evidence and implications within and across industrial countries", Journal of Economic Studies, Vol. 33 No.6, pp.406-36. 
McKinnon, R.I. (1973), Money and Capital in Economic Development, Brookings Institution Press, Washington, DC.

Romer, P. (1986), "Increasing returns and long-run growth", Journal of Political Economy, Vol. 94 No.5, pp.1002-37.

Roubini, N., Sala-i-Martin, X. (1995), "A growth model of inflation, tax evasion, and financial repression", Journal of Monetary Economics, Vol. 35 No.2, pp.275-301.

Schneider, F., Klinglmair, R. (2004), "Shadow economies around the world: what do we know?”, Discussion Papers No. 1043, IZA, Brussels.

Skinner, J., Slemrod, J. (1985), "An economic perspective of tax evasion", National Tax Journal, Vol. 38 No.3, pp.345-53.

Shaw, E.S. (1973), Financial Deepening in Economic Development, Oxford University Press, New York, NY.

\section{Further Reading}

Barro, R.J., Sala-i-Martin, X. (1992), "Public finance in models of economic growth", Review of Economic Studies, Vol. 59 No.4, pp.645-61.

Chari, V., Manuelli, R.E., Jones, L.E. (1996), "Inflation, growth, and financial intermediation", Quarterly Review, Federal Reserve Bank of Minneapolis, Vol. 78 No.3, pp.41-58.

\section{Corresponding author}

Rangan Gupta can be contacted at: Rangan.Gupta@up.ac.za 